\title{
Nefrotik Sendrom Tanılı Çocukların Son Beş Yılda Hastaneye Yatış Endikasyonları ve Prognozları
}

\section{Causes of Hospitalization and Prognosis of Children with Nephrotic Syndrome in The Last Five Years}

\author{
Bahriye ATMIŞ, Derya CEVIZLI, Aysun KARABAY BAYAZIT
}

Çukurova Üniversitesi Tıp Fakültesi, Çocuk Sağlığı ve Hastalıkları Anabilim Dalı, Çocuk Nefroloji Bilim Dalı, Adana, Türkiye

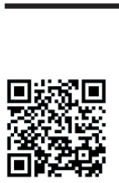

öz

Amaç: Bu çalışma ile kliniğimizde nefrotik sendrom tanısıyla takip edilen çocuklarda hastaneye yatış nedenlerinin belirlenmesi, klinik özelliklerinin incelenmesi ve prognozlarının değerlendirilmesi amaçlandı.

Gereç ve Yöntemler: Çalışmamızda Çukurova Üniversitesi Çocuk Nefroloji Bilim Dalında nefrotik sendrom tanısıyla takip edilen hastaların son beş yıldaki hastaneye yatış nedenleri incelendi. Halen takibimizde olan hastalar ise prognozları açısından değerlendirildi.

Bulgular: Çukurova Üniversitesi Tıp Fakültesi Çocuk Nefroloji servisine nefrotik sendrom tanısıyla 2015-2019 yılları arasında toplam 117 çocuk 299 kez yatııılı. Bu hastaların 58'i (\%49.6) kızdı. Hastaların ortalama yatış günü 9.98 16.91 gündü. Hastaların en sık yatış nedenleri ritüksimab infüzyonu (\%24.7), böbrek biyopsisi (\%22.1), pulse metilprednisolon (\%12.7), ağır ödem (\%12.4) ve enfeksiyonlardı (\%11). Takibe devam eden hastalar prognozları açısından incelendiğinde hastaların \%51.5'ü remisyonda iken \%17.4'üne evre 5 kronik böbrek hastalığı nedeniyle renal replasman tedavisi (RRT)

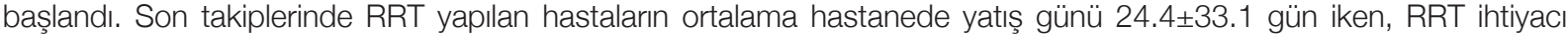
olmayan hastalarda $7.9 \pm 10.7$ gündü $(p<0.001)$. Hastaların hastanede toplam yatış süreleri ile mortalite arasında anlamlı bir ilişki saptanmadı ( $p=0.62)$. NS tanılı hastalarda RRT yapılması ile mortalite arasında anlamlı bir ilişki saptandı ( $p$ $<0.001)$.

Sonuç: Hastanemiz bölgemizde bir referans hastanesi olduğundan kliniğimizde çok sayıda NS tanılı çocuk hasta takip edilmektedir. Hastanede toplam yatış gün sayısı ile morbiditeye ve mortaliteye neden olan RRT ihtiyacı arasında anlamlı bir ilişkili bulunmuştur. Nefrotik sendromlu çocuk hastaların prognozu çoğunlukla iyi olsa da hayati tehdit edici komplikasyonlar ve mortalite görülebilmektedir.

Anahtar Sözcükler: Çocuk, Nefrotik sendrom, Prognoz, Yatış endikasyonu

\section{ABSTRACT}

Objective: The aim of this study was to determine the causes of hospitalization, to examine the clinical features and to evaluate the prognosis in children with nephrotic syndrome who were followed-up in our department.

Material and Methods: In this study, the causes of hospitalization in the last five years of the children with nephrotic syndrome who were followed-up in the Department of Pediatric Nephrology at Cukurova University were examined. The patients who are still under follow-up were evaluated in terms of their prognosis.

(1)

ATMIS B

CEVIZZIID

KARABAY BAYAZIT A
Çıkar Çatışması / Conflict of Interest: Tüm yazarlar adına, ilgili yazar çıkar çatışması olmadı̆ğııı belirtir.

0000-0002-1133-4845 0000-0001-6333-7522 0000-0002-2644-5628

(Tarih: 06/12/2019, Sayl: 94/9).
Yazarların katkısı / Contribution of the Authors: ATMIŞ B: Araștırma ve/veya makalenin hipotezini veya fikrini olușturan, Sonuçlara ulașmak için planlama/metodoloji belirleme, Araştırma/çalşmanın sorumluluğunu üstlenmek, ilerlemenin seyrini denetlemek, Hasta takibinde sorumluluk almak, ilgili biyolojik malzemelerin toplanması, veri yönetimi ve raporlama, deneylerin yürütülmesi, Sonuçların mantıksal olarak Yorumlanması ve sonuçlandırılması, Calıșma için gerekli literatür taramasında sorumluluk almak, Calısmanın bütününün veya önemli bölümlerinin yazımında sorumluluk almak, Yazım ve dilbilgisi dıșında bilimsel olarak gönderilmeden önce makaleyi gözden geçirme. CEVizLi D: Hasta takibinde sorumluluk almak, ilgili biyolojik malzemelerin toplanması, veri yönetimi ve raporlama, deneylerin yürütülmesi, Sonuçların mantıksal olarak Yorumlanması ve sonuçlandırılması, Çalıșma için gerekli literatür taramasında sorumluluk almak, Çalıșmanın bütününün veya önemli bölümlerinin yazımında sorumluluk almak, Yazım ve dilbilgisi dıșında bilimsel olarak gönderilmeden önce makaleyi gözden geçirme. KARABAY BAYAZIT A: Araştırma ve/veya makalenin hipotezini veya fikrini olușturan, Sonuçlara ulaşmak için planlama/metodoloji belirleme, Araştırma/çalıșmanın sorumluluğunu üstlenmek, ilerlemenin seyrini denetlemek, Hasta takibinde sorumluluk almak, ilgili biyolojik malzemelerin toplanması, veri yönetimi ve raporlama, deneylerin yürütülmesi, Sonuçların mantıksal olarak Yorumlanmas ve sonuçlandıııması, Çalıșma için gerekli literatür taramasında sorumluluk almak, Çalıșmanın bütününün veya önemli bölümlerinin yazımında sorumluluk ve sonuçlandırıması, Çalıșma için gerekli literatür taramasında sorumluluk almak, Çalıșmanın bü.
almak, Yazım ve dilbilgisi dıșında bilimsel olarak gönderilmeden önce makaleyi gözden geçirme.

Atıf yazım şekli / How to cite : Atmış B, Cevizli D, Karabay Bayazıt A. Nefrotik Sendrom Tanılı Çocukların Son Beș Yılda Hastaneye Yatış Endikasyonları ve Prognozları. Türkiye Çocuk Hast Derg 2022;16:200-204.;

Ek bilgi / Additional information: Bu çalş̧ma 18. Çukurova Pediatri Günlerinde 20-21 Şubat 2020 tarihinde sözel bildiri olarak sunulmuştur.
Yazıșma Adresi / Correspondence Address:

Çukurova Üniversitesi Tıp Fakültesi, Çocuk Sağlığı ve Hastalıkları Anabilim Dalı,

Çocuk Nefroloji Bilim Dalı, Adana, Türkiye

E-posta: bahriyeatmis@gmail.com
Geliş tarihi/ Received : :05.04.2021 Kabul tarihi / Accepted : 09.06.2021 Elektronik yayın tarihi : 14.09 .2021 Online published

DOI: 10.12956/tchd.906201 
Results: A total of 117 children were admitted to the Pediatric Nephrology ward 299 times between 2015-2019 with the diagnosis of nephrotic syndrome. Fifty-eight (49.6\%) of these patients were girls. The mean hospitalization day of the patients was $9.98 \pm 16.91$ days. The most common reasons for hospitalization were rituximab infusion (24.7\%), kidney biopsy (22.1\%), pulse methylprednisolone (12.7\%), severe edema (12.4\%) and infections (11\%). The patients who are still follow-up were examined in terms of their prognosis, $51.5 \%$ of the patients were in remission, while kidney replacement therapy (KRT) was initiated in $17.4 \%$ due to stage 5 chronic kidney disease. While the mean hospitalization day of the patients who underwent KRT in their last follow-up was $24.4 \pm 33.1$ days, it was $7.9 \pm 10.7$ days in patients who did not require KRT ( $p<0.001)$. There was no significant relationship between the length of stay in the hospital and mortality ( $p=$ 0.62). A significant relationship was found between performing KRT and mortality in children with NS ( $p<0.001)$.

Conclusion: Since our hospital is a reference hospital in our region, many pediatric patients with NS diagnosis are followed in our department. A significant correlation was found between the total length of stay in hospital and the requiring for KRT, which causes morbidity and mortality. Although the prognosis of children with nephrotic syndrome is usually good, life-threatening complications and mortality can be seen.

Key Words: Children, Nephrotic syndrome, Hospitalization, Prognosis

\section{GiRiş}

Nefrotik sendrom (NS) çocukluk çağında en sık görülen glomerüler hastallklardan biridir. Masif proteinüri (>40 mg/ $\left.\mathrm{m}^{2} / \mathrm{saat}\right)$, hipoalbuminemi $(<2.5 \mathrm{~g} / \mathrm{dL})$, ödem ve hiperlipidemi ile karakterizedir (1). Çocuklarda prevelansı 16/100000, ylllık insidansı ise 2-7/100000 olarak bildirilmiştir (2). NS'lu hastalar başlangıç yaşına, böbrek patoloji bulgularına ve steroid tedavisine verdikleri yanıta göre sınıflandırıı (3). Ayrıca NS'lu çocukların verilen steroid tedavisine yanıtına göre prognozları değişir. NS'lu seçilmiş vakalarda biyopsi gerekliliği, steroide dirençli vakalarda diğer intravenöz uygulanan immunsüpresif tedaviler ve çeșitli komplikasyonlar (enfeksiyon, akut böbrek hasarı, ağır ödem, tromboz) ile hastaneye yatış gerekmektedir. Bu çalışma ile kliniğimizde nefrotik sendrom tanısıyla takip edilen çocuklarda hastaneye yatış nedenlerinin belirlenmesi, klinik özelliklerinin incelenmesi ve prognozlarının değerlendirilmesi amaçlandı.

\section{GEREÇ ve YÖNTEMLER}

Çalışmamıza, Çukurova Üniversitesi Tıp Fakültesi Çocuk Nefroloji Bilim Dalında nefrotik sendrom tanısı ile izlenen 1-18 yaş arasında olan ve son beş yılda Çocuk Nefroloji servisine nefrotik sendrom tanısıyla yatan hastalar dahil edildi. Hastaların yașları, cinsiyetleri, biyokimyasal tetkikleri, histopatolojik tanıları, hastaneye yatış zamanları, hastaneye yatış endikasyonları, hastanede toplam yattıkları gün sayıları, hastaneye yatış sayıları kaydedildi. Ayrıca, bu hastalardan halen takibimizde olanların prognozları incelendi.

Hastalarda nefrotik sendrom tanısı Uluslararası Çocuk Böbrek Hastalıkları Çalışma Grubu (ISKDC) kriterlerine1 göre masif proteinüri (24 saatlik idrarda protein atılımı $>40 \mathrm{mg} / \mathrm{m}^{2} /$ saat veya sabah ilk idrarda protein/kreatinin $>2 \mathrm{mg} / \mathrm{mg}$ ), hipoalbuminemi $(2.5 \mathrm{~g} / \mathrm{dL})$ ve ödem varlığı ile konuldu. Remisyon, ödemin düzelmesi ile 24 saatlik idrarda protein atıımının $<4$ mg/m²/saat veya üç gün üste anlık idrar tetkikinde protein negatif veya eser olması olarak tanımlandı (1). Relaps, ödem ile birlikte 24 saatlik idrarda protein atıımının $>40 \mathrm{mg} / \mathrm{m}^{2} /$ saat veya üç gün üst üste spot idrarda protein +2 veya daha fazla olması olarak tanımlandı (1). Tahmini glomerüler filtrasyon hızı (eGFR), Schwartz formülü kullanılarak hesaplandı (4). Kronik böbrek hastalığı (KBH) evreleri KDIGO (Kidney Disease Improving Global Outcomes) Kllavuzuna göre eGFR $>90 \mathrm{ml} / \mathrm{dk} / 1.73 \mathrm{~m}^{2}$ ise evre $1 \mathrm{KBH}$, eGFR:60-89 ml/ $\mathrm{dk} / 1.73 \mathrm{~m}^{2}$ ise evre $2 \mathrm{KBH}$, eGFR:30-59 ml/dk/1.73 $\mathrm{m}^{2}$ ise evre $3 \mathrm{KBH}$, eGFR: $15-29 \mathrm{ml} / \mathrm{dk} / 1.73 \mathrm{~m}^{2}$ ise evre $4 \mathrm{KBH}$ ve eGFR $<15$ $\mathrm{ml} / \mathrm{dk} / 1.73 \mathrm{~m}^{2}$ renal replasman tedavisi (RRT) gerektiren kronik böbrek yetmezliği olup evre $5 \mathrm{KBH}$ olarak tanımlanmıştır (5).

Çalışma öncesinde Çukurova Üniversitesi Tıp Fakültesi Girişimsel Olmayan Klinik Araştırmalar Etik Kurulundan onay alındı (Tarih: 06/12/2019, Sayı: 94/9).

\section{İstatistiksel analiz}

İstatistiksel değerlendirme için SPSS 17.0 (SPSS, Chicago, IL, USA) kullanıldı. Kategorik değişkenler sayılar ve yüzde olarak ifade edilirken, sürekli değişkenler ortalama ve standart sapma olarak belirtildi. Sürekli değişkenler için dağlımın normalliği Shapiro-Wilk testi ile doğrulandı. Normal dağlıma uymayan sürekli değişkenlerin iki grup arasında karşılaştıııması için MannWhitney $U$ testi kullanıldı. Student t-test normal dağılan sürekli değişkenlerde gruplar arası sayısal değişkenleri karşılaştırmak için kullanıldı. $p$ değeri <0.05 istatistiksel olarak anlamlı kabul edildi.

\section{BULGULAR}

Çukurova Üniversitesi Tıp Fakültesi Çocuk Nefroloji servisine nefrotik sendrom tanısıyla 2015-2019 yllları arasında toplam 117 çocuk 299 kez yatıııld. Bu hastaların 58'i (\%49.6) kız, 59'u (\%50.4) erkekti. Yatış anında hastaların ortalama yaşı $9.85 \pm 5.22$ yıldı. Hastaların ortalama yatış günü $9.98 \pm 16.91$ gündü. Toplam 299 yatışın yıllar arasında dağıımına bakıldığında, 2015 yılında 66 yatış (\%22), 2016 yllında 58 yatış (\%19.4), 2017 yilında 43 yatış (\%14.4), 2018 yilında 44 yatış (\%14.7) ve 2019 yllında ise 88 yatış (\%29.5) bulundu. Hastaların hastaneye yatış sıklıklarına bakıldığında bir kez yatan hasta sayısı 55 (\%47), iki kez yatan hasta sayısı 24 (\%20.5), üç kez yatan hasta sayısı $11(\% 9,4)$ 
Tablo I: Nefrotik sendrom tanılı hastaların hastaneye yatış endikasyonları.

\begin{tabular}{|l|c|}
\hline \multicolumn{1}{c}{ Yatış nedeni } & n (\%) \\
\hline Rituksimab tedavisi & $74(24.7)$ \\
\hline Böbrek biyopsisi & $66(22.1)$ \\
\hline Pulse metilprednisolon & $38(12.7)$ \\
\hline Ağır ödem & $37(12.4)$ \\
\hline Enfeksiyonlar & $33(11)$ \\
\hline Ekulizumab tedavisi & $14(4.7)$ \\
\hline Pulse siklofosfamid & $9(3)$ \\
\hline Albümin tedavisi & $8(2.7)$ \\
\hline Plazmaferez & $6(2)$ \\
\hline Akut böbrek hasarı & $5(1.7)$ \\
\hline İleri tetkik & $4(1.3)$ \\
\hline Tromboz & $2(0.7)$ \\
\hline Diyabetes mellitus & $2(0.7)$ \\
\hline Konvülziyon & $1(0.3)$ \\
\hline Toplam & $299(100)$ \\
\hline
\end{tabular}

Tablo II: Takibe devam eden nefrotik sendrom tanılı hastaların prognozları.

\begin{tabular}{l|c}
\hline \multicolumn{1}{c}{ Prognoz } & n (\%) \\
\hline Remisyon & $53(51.5)$ \\
Devam eden proteinüri & $24(23.4)$ \\
\hline Renal replasman tedavisi & $11(10.7)$ \\
Hemodiyaliz & $4(3.8)$ \\
Periton diyalizi & $3(2.9)$ \\
Böbrek transplantasyonu & $6(5.8)$ \\
\hline Tekrarlayan relaps & $2(1.9)$ \\
\hline Evre 3 kronik böbrek hastalığı & $103(100)$ \\
\hline Toplam
\end{tabular}

ve dört veya daha fazla kez yatan hasta sayısı 27 (\%23.1)'di. Hastaların ortalama yatış sayısı $2.57 \pm 2.41$ 'di. NS tanılı hastaların en sık yatış nedenleri ritüksimab infüzyonu (\%24.7), böbrek biyopsisi (\%22.1), pulse metilprednisolon (\%12.7), ağır ödem (\%12.4) ve enfeksiyonlardı (\%11). NS tanılı hastaların hastaneye yatış endikasyonları Tablo I' de gösterilmiştir.

NS tanılı hastalar en sık kıŞ mevsiminde (\%30.3) yatırımıştı. Hastaların 15'i (\%12.8) Suriyeli mülteciydi. Hastaların 87'sine (\%74.3) böbrek biyopsisi yapılmıştı, biyopsi yapılan hastalar arasında en sık saptanan histopatolojik tanı minimal lezyon hastalığıydı (\%40.2). Böbrek biyopsisi yapılan hastaların histopatolojik tanıları Şekil 1'de gösterilmiştir.

Yüz on yedi hastanın 103'ü Çocuk Nefroloji Bilim dalında takibe devam etti. Takibe devam eden hastalar prognozları açısından incelendiğinde hastaların \%51.5'ü remisyonda iken \%17.4'üne evre 5 kronik böbrek hastalığı nedeniyle RRT başlandı (Tablo II). NS tanılı ve hemodiyaliz tedavisi yapılan iki hasta, böbrek

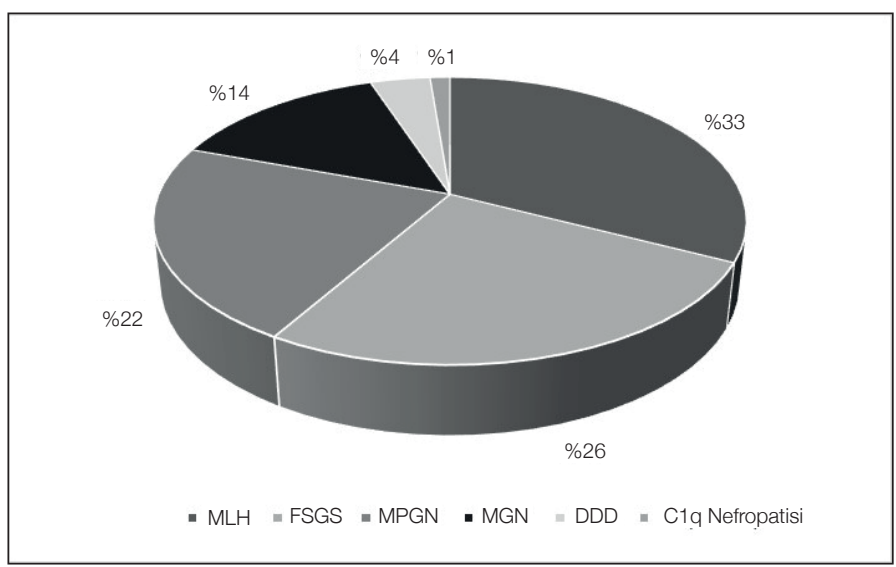

Şekil 1: Nefrotik sendrom tanılı hastaların histopatolojik tanılarına göre dağlımı. (MLH: minimal lezyon hastalı̆̆ı, FSGS: Fokal segmental glomerüloskleroz, MPGN: membranoproliferatif glomerülonefrit, $\mathbf{M G N}$ Membranöz glomerülonefrit, DDD: Dens depozit hastalığı)

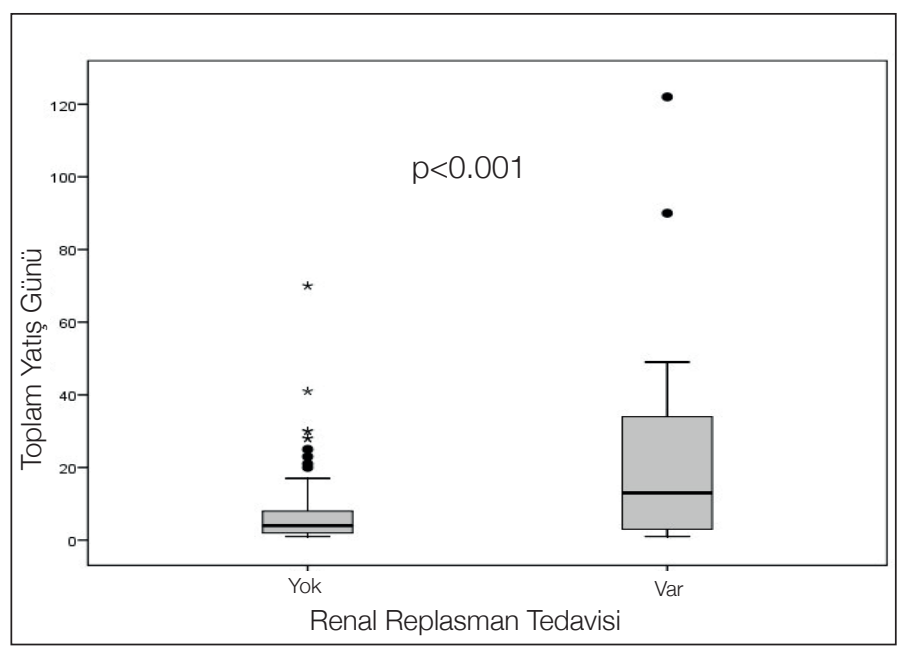

Şekil 2: Son kontrollerinde renal replasman tedavisi yapılan ve yapılmayan hastaların hastanede toplam yatış günleri.

transplantasyonu yapılan bir hasta ve periton diyalizi yapılan bir hasta öldü.

Hastaların hastaneye yatış sayısı ve toplam yatış günü kızlar ve erkekler arasında anlamlı farklılık göstermiyordu ( $p>0.05)$. Son takiplerinde RRT yapılan hastaların ortalama hastanede yatış

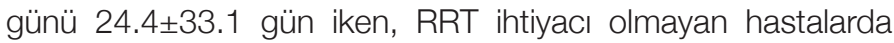
$7.9 \pm 10.7$ gündü $(p<0.001)$ (Şekil 2). NS tanılı hastaların hastanede toplam yatış süreleri ile mortalite arasında anlamlı bir ilişki saptanmadı ( $p=0.62)$. NS tanılı hastalarda RRT yapılması ile mortalite arasında anlamlı bir ilişki saptandı $(p<0.001)$.

\section{TARTIŞMA}

Nefrotik sendrom çocukluk çağında sık görülen glomerüler hastalıklardandır. NS'lu çocukların yaklaşık \%80'i minimal lezyon hastalığıdır. Hastaların steroide olan cevabı prognozun önemli bir göstergesidir. Steroide cevap verenlerde $\mathrm{KBH}$ gelişme 
riski çok düşüktür (6). NS tanılı çocukların takiplerinde relaps sırasında gelişen anazarka tarzında ödem, immunsüpresif tedavi infüzyonları, trombotik olaylar, enfeksiyonlar, akut böbrek hasarı $(\mathrm{ABH})$ gibi komplikasyonlarla veya RRT yapılmak üzere hastaneye yatış gerektirmektedir. Bu çalışmada üçüncü basamak bir hastane olan merkezimiz Çocuk Nefroloji bilim dalında NS tanısı ile takip edilen hastalardan son beș yilda yatış gerektiren 117 hastanın demografik, klinik ve histopatolojik özellikleri incelendi. Halen takibine devam eden 103 hasta ise prognozları açısından incelendi.

Literatürde bakıldığında NS'un erkeklerde kızlara oranda daha sık olduğu bildirilmiştir $(7,8)$. Bizim çalışmamızda ise E:K 1.02/1 olarak bulundu. Literatürden farklı olarak erkek ve kız hastaların oranlarının neredeyse aynı olmasının çalısmamızda sadece hastaneye yatış yapılan hastaların dahil edilmesi nedeniyle olduğu düşünülmektedir. Çalışmamıza dahil edilen hastalarda en sık saptanan histopatolojik tanılar literatürle uyumlu olarak sırasıyla MLH ve FSGS'di (9-11). YIImaz ve ark.(7) tarafından bildirilen ve 289 NS tanıı çocuk hastanın alındığı bir çalışmada 6 yaş altında böbrek biyopsisi yapılan hastalarda en sık patolojik tanı MLH iken ikinci sıklıkta FSGS bulunmuştur. Hacıhamdioğlu ve ark. (8) tarafından bildirilen bir çalışmada ise en sık histopatolojik tanının FSGS olduğu bildirilmiştir. Çalışmalarda histopatolojik tanı farklııklarının çalışmaya dahil edilen hastaların özellikleri ile ilgili olduğu düşünüldü.

Rheault ve ark. tarafından yapılan ve 336 NS tanılı çocuk hasta alındığı bir çalışmada hastaların 615 kez olan hastane yatışları değerlendirilmiştir (10). Üç ylllık çalışma periyodu boyunca hastaların \%60.1'i bir kez hastaneye yatarken, \%21.7'si iki kez, \%7.1'i üç kez ve \%11.1'i dört veya daha fazla kez hastaneye yattığı bildirilmiştir (10). Bizim çalışmamızda da benzer şekilde hastaların \%47'sinin bir kez hastane yatışı vardı. Kumar ve ark. bildirdiği bir çalışmada 148 NS tanılı çocuk hastanın 162 kez hastane yatışında en sık yatış nedenleri sırasıyla, anazarka tarzında ödem, enfeksiyon, hipovolemi, tetani ve hipertansif ensefalopati olarak bildirilmiştir (12). Ajayan ve ark. (13) hastaneye yatıș nedenleri arasında hastaların \%36.6'sında majör enfeksiyon bildirirken, Wei ve ark. (14) enfeksiyon nedeniyle ile yatış oranını \%18 olarak bildirmişlerdir. Bizim çalışmamızda ise enfeksiyon nedeniyle yatış oranı \%11 olarak bulundu. Literatürde NS'lu çocuk hastaların hastaneye yatış nedenleri arasında farklılıkların olması çalışmanın yapıldığı hastanenin özellikleri, çalışmanın süresi ve çalışmaya dahil edilen hasta sayıları ile ilişkili olduğu düşünülmektedir.

Literatürde NS tanılı çocukların hastane yatışlarında ABH sıklığını araştıran bir çalışmada hastaların \%50.9'unda $\mathrm{ABH}$ geliştiği bildirilmiştir (10). Başka bir çalışmada ise 10 yılda 508 NS tanıı çocuk hastanın hastaneye yatış nedenleri arasında $\mathrm{ABH}$ sıklığı \%1 olarak bildirilmiştir (14). Bizim çalışmamızda da benzer şekilde ABH sıklığı \%1.7 oranında bulundu. Çalışmamızda ilk çalışmaya göre $\mathrm{ABH}$ sıklığının daha az saptanmasının nedeni hastaların sadece hastaneye yatış nedenleri arasında $\mathrm{ABH}$ sıkığına bakılması ve yattığı sürede gelişen $\mathrm{ABH}$ ataklarının dahil edilmemesidir.

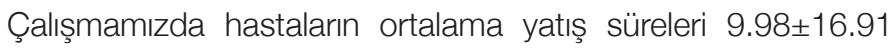
gündü. Kumar ve ark. ise çalışmalarında hastaların ortalama yatış süreleri $10 \pm 6.8$ gün olarak bildirmişlerdir (12). Aynı çalışmada enfeksiyon nedeniyle yatan hastaların hastanede yatışları ortalama $12 \pm 8$ gün iken enfeksiyon dışı nedenlerle yatan hastaların ortalama yatış süreleri $8 \pm 5$ gün olarak bildirilmiştir $(p<0.001)$ (12). Wei ve ark. (14) Tayvan'dan 10 yıllık periyodda 176 NS tanıı hastanın 508 yatışını inceledikleri çalışmalarında benzer şekilde enfeksiyon varlığının hastanede yatış süresini uzattığı bildirilmiştir.

Wei ve ark.(14) çalışmasında NS tanılı çocukların hastaneye yatışları mevsimlere göre değerlendirildiğinde enfeksiyon nedeniyle yatışların en sık ilkbaharda yapıldığı, enfeksiyon dışı nedenlerle yatışların ise en sık yaz mevsiminde yapıldığı bildirilmiştir. Bizim çalışmamızda ise tüm hastalarda en sık yatış yapılan mevsim kıştı. Çalışmamızdaki bu farklıı̆ı̆ın nedeni olarak iki çalışmadaki yatış nedeni sıkıklarının farklı olmasıdır.

Hastaların prognozları açısından değerlendirdiğimizde halen takip edilen 103 hastanın \%17.4'ünde evre 5 KBH nedeniyle renal replasman tedavisi başland. Literatürde $631 \mathrm{NS}$ tanılı çocuk hastanın alındığı bir çalışmada hastaların \%1.7'sinde ortanca 3.9 yll takip süresi sonunda evre $5 \mathrm{KBH}$ geliştiği bildirilmiştir (15). Sadece steroide dirençli NS tanilı çocuk hastaların alındığı bir çalışmada ise hastaların \%26.8'inde evre 5 KBH geliştiği bildirilmiştir (16). Ülkemizden bildirilen bir çalışmada ise 3 ylllik takip sonunda kronik böbrek yetmezliği oranı \%7.7 iken 5 ylllik takip sonunda bu oran \%9 olarak bildirilmiştir (8). Çalışmalardaki evre $5 \mathrm{KBH}$ gelişen hastaların oranlarındaki farklııkların çalışmaya alınan hastaların farklı gruplardan (yatan hastalar, sadece steroide dirençli NS tanilı hastaların vb.) olması nedeniyle olduğu düşünülmektedir.

Çalışmamızda kliniğimizde takibe devam eden 103 hastada mortalite RRT tedavisi yapılan dört hastada (\%3.88) görüldü. Bu hastaların hastanede toplam yatış süreleri diğerlerine göre anlamlı olarak daha uzun bulundu. Literatüre bakıldığında ise Trompeter ve ark. (17) steroide yanıtlı NS tanılı 152 çocuk hastanın uzun dönem prognozunu bildirdiği çalışmalarında 11 ölüm görülmüştür. Prasad ve ark. (18) ise hastaneye yatışlarda $\mathrm{ABH}$ gelişen NS tanılı 13 hastanın üçünde ölüm olduğunu bildirmişlerdir. Carter ve ark. (15) bildirdiği çalışmada ise 631 NS tanılı çocuk hastanın ortanca 3.9 yll takipleri boyunca ölen hastaları olmamıştır. Uzun dönem prognozu genellikle iyi olan NS tanilı çocuklarda gelişen komplikasyonlar mortaliteyi ve morbiditeyi arttırmaktadır.

Çalışmamızın retrospektif olarak yapııması ve çalışma süresinin beş yıllık bir periyod olarak belirlenmesi çalışmamızın kısıtllıklarındandır. 
Sonuç olarak, hastanemiz bölgemizde bir referans hastanesi olduğundan kliniğimizde çok sayıda NS tanilı çocuk hasta takip edilmektedir. Çalışmamızda nadir olmayan sıklıkta hayati tehdit edici komplikasyonlar ile yatan bu hastalarda hastanede toplam yatış gün sayısı ile morbiditeye ve mortaliteye neden olan RRT intiyacı arasında anlamlı bir ilișkili bulunmuştur. Nefrotik sendromlu çocuk hastaların prognozu çoğunlukla iyi olsa da hayati tehdit edici komplikasyonlar ve mortalite de görülebilmektedir.

\section{KAYNAKLAR}

1. The primary nephrotic syndrome in children: Identification of patients with minimal change nephrotic syndrome from initial response to prednisone. A report of the International Study of Kidney Disease in Children. J Pediatr 1981;98:561-4.

2. Eddy AA, Symons JM. Nephrotic syndrome in childhood. Lancet 2003;362:629-39.

3. Rheault MN. Nephrotic syndrome. In Kher KK, Schnaper HW, Greenbaum LA (eds). Clinical Pediatric Nephrology. Third Edition. Boca Raton: CRC press, 2017:285-303.

4. Schwartz GJ, Muñoz A, Schneider MF, Mak RH, Kaskel F, Warady BA, et al. New equations to estimate GFR in children with CKD. J Am Soc Nephrol 2009;20:629-37.

5. KDIGO 2012 Clinical Practice Guideline for the Evaluation and Management of Chronic Kidney Disease. Kidney Int Suppl 2013;3:1-150.

6. Niaudet P, Boyer O. Idiopathic Nephrotic Syndrome in Children: Clinical Aspects. In Avner ED, Harmon WE, Niaudet P, Yoshikawa N, Emma F, Goldstein SE (eds). Pediatric Nephrology. 7th edition. Berlin Heidelberg: Springer-Verlag 2016:830-82.

7. Yılmaz K, Düşünsel R, Dursun İ, Yel S, Gündüz Z, Poyrazoğlu H. Idiopathic Nephrotic Syndrome in Childhood: A Retrospective
Analysis of Two Hundred and Eighty Nine Patients. Med Bull Haseki 2017;55:280-5.

8. Hacıhamdioğlu DÖ, Kalman S, Faysal Gök F. Long-term results of children diagnosed with idiopathic nephrotic syndrome; single center experience. Turk Pediatri Ars 2015;50:37-44.

9. Internationale Study of Kidney Disease in Children; prediction of histopathology from clinical and laboratory characteristics at time of diagnosis, Kidney Int 1978;13:159-65.

10. Rheault MN, Zhang L, Selewski DT, Kallash M, Tran CL, Seamon $\mathrm{M}$, et al. AKI in Children Hospitalized with Nephrotic Syndrome. Clin J Am Soc Nephrol. 2015 Dec 7;10(12):2110-8.

11. Carpenter SL, Goldman J, Sherman AK, SelewskiDT, Kallash M, Tran $\mathrm{CL}$, et al. Association of infections and venous thromboembolism in hospitalized children with nephrotic syndrome. Pediatr Nephrol 2019; 34:261-7.

12. Kumar M, Ghunawat J, Saikia D, Manchanda V. Incidence and risk factors for major infections in hospitalized children with nephrotic syndrome. Braz J Nephrol 2019;41:526-33.

13. Ajayan P, Krishnamurthy S, Biswal N, Mandal J. Clinical spectrum and predictive risk factors of major infections in hospitalized children with nephrotic syndrome. Indian Pediatr. 2013;50:779-81.

14. Wei CC, Yu IW, Lin HW, Tsai AC. Occurrence of infection among children with nephrotic syndrome during hospitalizations. Nephrology (Carlton) 2012 ; 17:681-8.

15. Carter SA, Mistry S, Fitzpatrick J, Banh T, Hebert D, Langlois V, et al. Prediction of Short- and Long-Term Outcomes in Childhood Nephrotic Syndrome. Kidney Int Rep 2019;5:426-34.

16. Trautmann A, Schnaidt S, Lipska-Zietkiewicz BS, Bodria M, Ozaltin F, Emma F, et al. Long-term outcome of steroid-resistant nephrotic syndrome in children. J Am Soc Nephrol 2017;28:3055-65.

17. Trompeter RS, Lloyd BW, Hicks J, White RH, Cameron JS. Long-term outcome for children with minimal-change nephrotic syndrome. Lancet 1985;1:368-70.

18. Prasad BS, Kumar M, Dabas A, Mishra K. Profile of Acute Kidney Injury in Hospitalized Children with Idiopathic Nephrotic Syndrome. Indian Pediatr 2019;56:119-22. 